\title{
Etnopolítica e Estado : centralização e descentralização no movimento indígena brasileiro
}

Ethnopolitics and the State: Centralization and descentralization in the Brazilian indigenous movement

\section{Andrey Cordeiro Ferreira}

\section{(2) OpenEdition}

\section{Journals}

Edição electrónica

URL: http://journals.openedition.org/aa/1709

DOI: 10.4000/aa.1709

ISSN: 2357-738X

Editora

Programa de Pós-Graduação em Antropologia Social (UnB)

Edição impressa

Data de publição: 1 julho 2017

Paginação: 195-226

ISSN: 0102-4302

Refêrencia eletrónica

Andrey Cordeiro Ferreira, «Etnopolítica e Estado : centralização e descentralização no movimento indígena brasileiro», Anuário Antropológico [Online], v.42 n. 1 | 2017, posto online no dia 08 junho 2018, consultado o 27 abril 2021. URL: http://journals.openedition.org/aa/1709 ; DOI: https://doi.org/ 10.4000/aa. 1709

\section{(c) $\underset{\mathrm{EY}}{(\mathrm{NQ})}$}

Anuário Antropológico is licensed under a Creative Commons Atribuição-Uso Não-Comercial-Proibição de realização de Obras Derivadas 4.0 International. 


\title{
Etnopolítica e Estado: centralização e descentralização no movimento indígena brasileiro
}

\author{
Andrey Cordeiro Ferreira
}

UFRRJ

\section{A política e o "político" como objeto:}

\section{da naturalizaçáo do Estado à etnopolítica}

O que entendemos pelo conceito de política? A pergunta, aparentemente de resposta simples quando recorremos à definição etimológica ("atividade de gestão da polis"), ganha contornos completamente distintos quando lembramos que a palavra recobre múltiplos significados dentro de diferentes teorias e sociedades. $\mathrm{O}$ conceito de política, gerado ele mesmo na história e nas formaçôes sociais do "Ocidente", leva uma carga de eurocentrismo, já que a política, nascendo no âmbito da cidade-Estado, fez com que sua própria definição colocasse como seu centro a noção de Estado. Sendo a política definida como atividade que supóe o Estado, todas as formas que não são estatais são "não" ou "pré" políticas. Esse foi o ponto de partida das grandes narrativas filosóficas dos séculos XVIII e XIX, nas quais se elaboraram as teorias sobre o Estado moderno e se definiram conceitos como sociedade civil e política, ocorrendo o que poderíamos chamar de naturalização do conceito do Estado, que passou a ser um ente necessário e dado (Balandier, 1969; Poulantzas, 1977; Weffort, 2001).

Essa definição estrita de política foi problematizada de diferentes maneiras na teoria antropológica. A antropologia política teve uma longa tradição de desnaturalização dos conceitos de Estado e política, especialmente pelo fato de se defrontar com uma multiplicidade histórica de formas de política, no estudo das chamadas sociedades primitivas, tradicionais ou pré-capitalistas (Balandier, 1969; Clastres, 2003; Evans-Pritchard, 1978; Leach, 1995; Radcliffe-Brown, 1981). A antropologia operou o que podemos chamar de ampliaçáo do conceito de política para abarcar as formas e os sistemas das sociedades da periferia (tanto os chamados Estados tradicionais quanto as sociedades sem Estado). Essa ampliação do conceito de política para expressar atividades societárias, e não meramente estatais, foi sucedida pelas críticas pós-estruturalistas, que pluralizaram de forma definitiva o conceito de política, permitindo o surgimento de conceitos como o de micropolítica (como política dos grupos e das instituiçôes) e o de infrapolítica (política invisível de resistência prática e simbólica), que antes eram negados como tais (Foucault, 1979; Scott, 2000). Nicos Poulantzas (1977) criou, tomando por 
base essas críticas da antropologia, a distinção entre o "político", como instância ou aparelho especializado de exercício do poder político (no qual se enquadra, por exemplo, o Estado), e a "política", como atividade social englobante de manifestaçóes históricas diversas, inclusive de sociedades sem estado. Podemos afirmar, então, que a principal contribuição da antropologia foi redefinir o conceito de política, que passou a englobar uma pluralidade histórica, sendo assim um conceito relativo, não absoluto, e restrito ao de Estado. Trata-se náo somente de uma multiplicidade semântica, mas de uma multiplicidade de formas históricas reais de objetivação da política.

O estudo dos chamados Estados primitivos ou tradicionais, das sociedades sem Estado e segmentares, antecederam e, em certa medida, fundaram o que estamos chamando aqui de etnopolítica, ou seja, um objeto distinto do estudo (diferente do "político" como sinônimo de atividade especializada do Estado moderno). ${ }^{1}$ Enquanto a sociologia e a ciência política se debruçaram normalmente sobre o estudo do político, a antropologia social se debruçou sobre o estudo dos tipos de etnopolítica. Obras como Sistemas politicos africanos, Os Nuer (EvansPritchard, 1978) e A sociedade contra o Estado (Clastres, 2003) são fundadoras dessa abordagem. O estudo do sistema político, nessas obras, tinha algumas características emblemáticas: a) a descrição dos modos de subsistência e das condiçôes ecológicas das sociedades africanas e como estas condiçôes estavam associadas ao sistema político e à estrutura social; b) a oscilação da política nas sociedades africanas em função do que denominaram de princípio de fusão (união dos grupos) e fissão (divisão dos grupos) dos grupos de linhagem; c) a existência, no caso da tese de Clastres sobre os índios sul-americanos, de uma profunda desconfiança dos grupos em relação aos chefes indígenas e vários mecanismos de regulação social do seu poder.

Como observaram autores como Leach (1995), esta abordagem, entretanto, pecava por ser essencialmente "estática", pois se concebia que a unidade do grupo estava dada a priori pelas regras funcionais, de forma que os conflitos e o processo de divisão nunca exacerbava os limites da unidade e coesão do grupo, ou ainda, na tese da sociedade contra o Estado, se tendia a diminuir as ambiguidades das relaçóes dos povos indígenas com o Estado, idealizando uma espécie de anarquia primitiva (Ferreira, 2011). Nessas abordagens, os sistemas políticos africanos seriam exteriores à modernidade (apesar de escritas sob o colonialismo, as etnografias desconsideravam a situação colonial) ou, no caso dos indígenas das terras baixas sul-americanas, sua condição de indígena estava associada à sua filosofia antiestatista, que os deixava, assim, fora do Estado (apesar de igualmente estes povos terem sido englobados pelos Estados modernos nas Américas). 
Foram obras como Local level politics (Swartz, 1968) que promoveram uma profunda revolução no estudo da antropologia política, e autores como Fredrik Barth, Max Gluckman, Edmund Leach e Victor Turner ${ }^{2}$ que contribuíram para uma visão dialética da etnopolítica. Todos eles chamaram atençáo para o fato de que o que foi chamado de dinâmica fissão/fusão eram processos sociais competitivos e desarmônicos, ou seja, os conflitos que tinham o poder de transformar a estrutura social. ${ }^{3}$ Por outro lado, uma importante crítica sintetizada no conceito de nível local da política era de que as instituiçóes "indígenas e tradicionais" pertenciam ao mesmo campo de atividade que instituiçóes coloniais e estatais, se interpenetravam, conformando uma rede que ia do local ao mundial, não fazendo sentido pensar os sistemas políticos assim, em condição estática ou de insulamento cultural e histórico (Gluckman \& Swartz, 1966; Swartz, Turner $\&$ Tuden, 1966).

Turner avançou ainda mais e elaborou a ideia de uma dialética entre estrutura social (que tinha propriedades hierárquicas e centralizadoras) e antiestrutura (formas emergentes de conflitos sociais que negavam os aspectos da estrutura social, mesmo que de forma temporária, afirmando os aspectos horizontais das relaçóes sociais), concebendo que a dialética era característica da política em geral, e não apenas da etnopolítica. Assim, em grande medida, acontecimentos históricos que envolviam açóes coletivas, movimentos sociais e revoluçóes poderiam ser pensados como uma dialética ou luta entre a estrutura social (ou seja, a cultura, a economia e o sistema político dominantes na sociedade global) e a antiestrutura, como ele realizou para análise das insurreiçóes mexicanas no século XIX (Swartz, 1968; Swartz, Turner \& Tuden, 1966; Turner, 2008). Essas elaboraçóes retomaram vários aspectos da teoria da política, ${ }^{4}$ como a dialética, que estabeleceu que toda atividade política pode ser pensada pela oscilação entre duas categorias, autoridade e liberdade, que são as bases da atividade política, dos regimes e das formas de governo (Ferreira, 2014b; Proudhon, 1986, 2001). Todas as formas concretas da política seriam expressôes da tensão entre estes princípios e de equilíbrios concretos entre eles, tratando-se então, para o estudo da política, de compreender as formas concretas da relação entre autoridade e liberdade ou centralização e descentralização.

A antropologia social deu, então, uma importante contribuição para a construçáo de um conceito amplo de política. Ao mesmo tempo, lançou algumas hipóteses sobre a dinâmica dialética que rege o que estamos chamando aqui de etnopolítica. É exatamente essa abordagem que iremos desenvolver.

A antropologia estabeleceu também algumas das principais bases das teorias da etnicidade. E não é possível falar de etnopolítica sem definir, minimamente, 
etnicidade. 5 Aqui, tomamos como pressuposto as elaborações de autores como Barth (1976), Sider (1993), Oliveira Filho (1999) e Adams e Bastos (2003). Na abordagem de tais autores, a etnicidade deve ser pensada em função de algumas consideraçóes fundamentais. Primeiro, que as identidades e os grupos étnicos são formas de organização social, não unidades biológicas ou culturais prédeterminadas. Isso significa que os grupos étnicos não são unidades sociais préhistóricas, pré-capitalistas ou primitivas, ao contrário, são formas de organização historicamente determinadas, que surgem, se transformam, eventualmente desaparecem e ressurgem. Os grupos étnicos existem sempre dentro de um sistema social abrangente, no qual se dá a interdependência de grupos, e não o isolamento cultural e natural - perspectiva expressa na ideia do sistema poliétnico "integrado no âmbito do mercado e dominado por um sistema estatal controlado por um dos grupos" (Barth, 2000:35).

Segundo, que os sistemas interétnicos são sempre o produto da interação de uma hierarquia de classificaçóes simbólicas; da existência de uma hierarquia entre esferas econômicas (mercado mundial, circuitos de reciprocidade); e de uma hierarquia do poder político (estatal ou náo) que regula o conjunto das relaçôes interétnicas. Deste modo, quando falamos em etnicidade, que qualifica a etnopolítica, estamos falando necessariamente de uma região em que essas hierarquias simbólicas, econômicas e políticas se entrecruzam. A etnicidade não é um fenômeno exclusivamente cultural, mas é concebida aqui como uma construção histórica que remete aos fundamentos ecológicos, políticos e culturais. Desse modo, quando falamos que a etnopolítica está embebida na organização social, significa que para compreendê-la é preciso compreender a história de transformações dos grupos e sistemas interétnicos, especialmente sua posição na situação colonial (Balandier, 1993; Oliveira Filho, 1999), suas formas de organização interna e sua posição nas relaçóes ou sistemas interétnicos.

Podemos definir a etnopolítica como conceito que demarca um objeto específico: a atividade política de grupos étnicos (ou de sistemas interétnicos) que contém marcas de sua experiência histórica, organização social, cultura e base material-ecológica. Mas essa definição, por si mesma, é tautológica. Podemos dizer entáo, de forma mais precisa, que a etnopolítica abrange, por um lado, o estudo da micropolítica (as relaçôes de poder internas às instituiçóes e grupos sociais, bem como as regiooes não exclusivamente políticas, como parentesco, cosmologia etc.), da infrapolítica (ou da atividade que, sem lentes etnográficas, seria invisível, de resistência e conflitualidade dos grupos em face das estruturas de poder) e do nível local da política (das redes de instituiçóes e poderes estatais e coloniais integrantes de um sistema mundial). Desse modo, 
seguindo essa tradição de desnaturalização do conceito de política, propomos distinguir o estudo do "político" (como sinônimo de estudo das atividades do Estado) e o estudo da "política" (como uma pluralidade de formas históricas), sendo a etnopolítica o conceito que demarca como objeto um modo específico de fazer política, a de grupos e sistemas interétnicos, embebida nas estruturas sociais e simbólicas da etnicidade.

\section{A experiência do movimento indígena:}

\section{micropolítica, centralizaçáo e limites da unidade}

É com base nesses pressupostos que iremos estudar a história do movimento indígena e das lutas entre centralização e descentralização em seu interior, como um tipo de micropolítica de uma organização. Essa micropolítica, por sua vez, é condicionada pelas formas de infrapolítica e a posição destas no nível local da política.

Para falar do movimento indígena no Brasil, é preciso distinguir os sentidos do termo. A categoria "movimento" não figura apenas na teoria sociológica e política. É uma categoria etnográfica. Entre os indígenas, trabalhadores rurais e urbanos, é comum usar o termo "movimento". Movimento, do ponto de vista dos atores, como categoria êmica, significa algum tipo de ação reivindicatória, ampla e difusa, e todos que participam dessas ações. O termo "movimento indígena” comporta a mesma ambiguidade. Pode designar ativistas isolados, pessoas comprometidas moralmente com uma causa, organizaçóes formalmente estruturadas e suas principais táticas de ação.

De maneira geral, a ideia de movimento evoca a imagem de uma unidade transcendente; todos que integram o movimento compartilham uma ética, uma identidade, objetivos, ou todas essas coisas ao mesmo tempo. Como forma discursiva e de organização social, o movimento indígena gera uma associação de identidades étnicas específicas à identidade genérica de índio ${ }^{6}$ e leva à constituição de unidades de mobilização que reorganizam relaçóes familiares, territoriais e étnicas, visando à intervenção num sistema político englobante. $\mathrm{O}$ movimento indígena, nesse sentido, compreende diferentes formas organizativas - desde organizaçóes locais, formas associativas culturais e produtivas, assembleias indígenas, até organizaçôes de abrangência nacional com pretensão de articulação política (Oliveira Filho, 2006).

Entendemos o movimento indígena de duas maneiras: como categoria êmica, é uma forma discursiva de produzir a unidade, de ajudar a gerar um sistema interétnico e constituí-lo como ator político; em termos sociológicos, é um 
conjunto mais ou menos difuso de formas organizativas e de ação, que tenta reunir grupos étnicos integrados em diferentes situaçôes e sistemas interétnicos.

Analisaremos o movimento indígena a partir de uma de suas expressóes possíveis, as organizaçóes indígenas de caráter nacional, que pretendem instituir o que poderíamos chamar de uma centralizaçáo organizacional. Para isso, situaremos o surgimento do movimento indígena, das experiências de construção de organizações indígenas, e descreveremos como este processo de centralização organizacional é marcado por contradiçôes, especialmente oriundas dos sistemas interétnicos regionais onde se encontram os grupos indígenas.

Focalizamos as organizaçóes indígenas nacionais, da qual a principal é a Articulação dos Povos Indígenas do Brasil (Apib), criada entre 2005 e 2006. A Apib é composta pela Articulação dos Povos e Organizações Indígenas do Nordeste, Minas Gerais e Espírito Santo (Apoinme), pela Articulação dos Povos Indígenas do Pantanal e Região (Arpipan), pela Articulação dos Povos Indígenas do Sudeste (Arpinsudeste), pela Articulação dos Povos Indígenas do Sul (Arpinsul), pela Grande Assembleia do Povo Guarani (ATY GUASSÚ) e pela Coordenação das Organizaçôes Indígenas da Amazônia Brasileira (Coiab), tendo uma comissão permanente, que funciona em Brasília, e o Acampamento Terra Livre como espaço deliberativo.

No sentido aqui empregado, o movimento indígena pode ser considerado uma forma organizativa intercultural surgida nos anos 1970 na América Latina (Batalla, 1978; Oliveira, 2013; Oliveira Filho, 2006). No Brasil, entretanto, a maioria das organizaçóes indígenas surgiram depois da democratização e da Constituição de 1988 (Oliveira, 2013; Shröeder, 2013). Ele é, assim, um tipo de sistema interétnico, que institui um processo de centralização organizacional, de que falaremos adiante. Podemos, seguindo a periodização proposta por alguns autores (Bicalho, 2010; Oliveira Filho, 2006), falar de dois ciclos: o primeiro abrange os anos 1970 e 1980, as primeiras assembleias indígenas e a mobilização contra as políticas da ditadura militar, bem como a mobilização pela inclusão de direitos indígenas na Constituinte de 1987/1988. O segundo ciclo pode ser definido como o das lutas contra os efeitos do neoliberalismo, pós-redemocratização, sendo marcado pelas mobilizaçóes de protesto contra os 500 anos de descobrimento, em 1999-2000, e pela realização do Primeiro Acampamento Terra Livre em 2004, que se tornou o principal espaço de mobilização do movimento indígena no Brasil (Bicalho, 2010; Oliveira, 2013; Pacheco de Oliveira; Rocha Freire, 2010).

O quadro a seguir sintetiza a história da formação das organizaçôes indígenas nacionais e de algumas organizaçóes indígenas no Mato Grosso do Sul. Desde o primeiro momento, os povos indígenas sul-mato-grossenses cumpriram um 
importante papel no movimento indígena, já que várias lideranças expressivas das primeiras organizações indígenas eram da etnia Terena. Por isso, indicamos na cronologia o processo de formação das organizaçóes indígenas nacionais e algumas regionais, incluindo o Mato Grosso do Sul. A cronologia nos mostra que existiram pelo menos três grandes experiências de construção de organizações indígenas, que iam da escala nacional à local: nos anos 1980-1990, a tentativa da União das Naçôes Indígenas (UNI/Unind); a criação do Conselho de Articulação dos Povos Indígenas do Brasil (Capoib), em 1995, que perdurou até o movimento Brasil Outros 500; e, finalmente, a constituição da Apib em meados dos anos 2000.

Quadro 1 - História da formação das organizaçóes indígenas nacionais e sul-mato-grossenses

\begin{tabular}{|c|c|c|c|c|}
\hline & 1980 & 1990 & 2000 & 2010 \\
\hline Brasil & $\begin{array}{l}\text { União das } \\
\text { Nações } \\
\text { Indígenas }\end{array}$ & $\begin{array}{c}\text { Criação do } \\
\text { Capoib (1995) }\end{array}$ & $\begin{array}{c}2000 \text { - Crise } \\
\text { interna do } \\
\text { Capoib } \\
\text { 2005-2006 - } \\
\text { Criação da Apib }\end{array}$ & \\
\hline Mato Grosso do Sul & $\begin{array}{l}\text { Criação do } \\
\text { Conselho } \\
\text { Aty Guasu } \\
\text { (Assembleia } \\
\text { Guarani) }\end{array}$ & $\begin{array}{c}\text { Criação de } \\
\text { inúmeras } \\
\text { associações } \\
\text { civis }\end{array}$ & $\begin{array}{c}\text { Criação de } \\
\text { inúmeras } \\
\text { associações } \\
\text { civis }\end{array}$ & $\begin{array}{l}\text { 2011/12 - Criação } \\
\text { e crise da Arpipan } \\
2012 \text { - Criação do } \\
\text { Conselho do Povo } \\
\text { Terena }\end{array}$ \\
\hline Amazônia e Nordeste & $\begin{array}{l}1989- \\
\text { Criação da } \\
\text { Coiab }\end{array}$ & $\begin{array}{c}1990 \text { - Criação } \\
\text { da Comissão } \\
\text { de Lideranças } \\
\text { Nordeste } \\
1995 \text { - } \\
\text { Transformação } \\
\text { da comissão na } \\
\text { Articulação dos } \\
\text { Povos Indígenas } \\
\text { do Nordeste, } \\
\text { Minas Gerais e } \\
\text { Espírito Santo } \\
\text { (Apoinme) }\end{array}$ & & \\
\hline
\end{tabular}

Fonte: Elaboração própria. 
O primeiro ciclo de tentativas de constituição de uma organização indígena nacional se deu entre 1980 e 1990. Elas eram iniciativas que envolviam líderes indígenas de Mato Grosso do Sul (Terena e Guarani) e estudantes indígenas radicados em Brasília. A Unind surgiu em Brasília, pela articulação de um grupo de estudantes indígenas que se organizou para cobrar recursos da Fundação Nacional do Índio (Funai). Outro grupo, formado por lideranças tradicionais locais, levou o nome de UNI, sendo criado em Campo Grande (MS). Numa reuniāo em 1980, essas duas formas associativas teriam se fundido, mas mantendo uma profunda tensão entre si (Bicalho, 2010:270). Emblematicamente, as duas primeiras presidências da entidade foram dos Terena Domingos Veríssimo Marcos ${ }^{7}$ e Mariano Marcos. A trajetória da UNI foi marcada por diversas contradiçóes que levaram à sua extinção, no início dos anos 1990, especialmente problemas oriundos da centralização de poder e recursos, ${ }^{8}$ acentuada pelo fato de diversas políticas terem induzido à descentralização do Estado e à formação de associações como pré-condição para acesso a recursos (Jackson \& Warren, 2005). Desse modo, a centralização organizacional, representada pela experiência da UNI, foi sucedida por uma nova descentralização organizacional, com a explosão de um grande número de associações indígenas locais e regionais.

O segundo ciclo começou com as lutas por demarcação de terras indígenas, nos marcos da Constituição Federal de 1988 e contra o neoliberalismo (anos 1990-2000). Nesse segundo ciclo, temos alguns processos fundamentais. O principal foi o esforço de "regionalização", com a criação de organizaçóes como a Coiab e a Apoinme, entre 1990 e 1995. Essas duas organizaçôes regionais, bem como o Conselho Indigenista Missionário (Cimi), foram essenciais para criar uma nova proposta de organização indígena nacional, o Capoib. A tentativa de criação do Capoib gerou um deslocamento em relação à experiência da UNI/ Unind, que teve um papel destacado nas figuras dos líderes indígenas do Mato Grosso do Sul. A emergência das organizaçóes e lideranças do Nordeste e da Amazônia trouxe ao centro do movimento indígena as contradiçóes vivenciadas pelos povos indígenas do Brasil: sua divisão em povos com terra (especialmente aqueles localizados na Amazônia legal) e povos sem terra, em luta por demarcação (como é o caso no Nordeste).

Essa e outras contradições manifestaram-se na experiência de construção do Capoib e no movimento Brasil Outros 500, que resultou na realização da Conferência dos Povos e Organizaçóes Indígenas e na Marcha Indígena 2000. A Conferência dos Povos e Organizaçóes Indígenas deveria ser a ocasião da consolidação da Capoib, entretanto, isso não ocorreu. Houve uma luta interna entre setores do movimento indígena durante os protestos dos 500 anos de Brasil, 
o que fez com que a proposta da Capoib entrasse em crise (Bicalho, 2010; Ferreira, 2008). A principal acusação era de centralização de poder e recursos. ' A segunda experiência de construção de uma organização indígena nacional fracassou. Mas os esforços para tal construçáo continuaram.

Entre 2005 e 2006, formou-se outra organização indígena nacional, por ocasião do Primeiro Acampamento Terra Livre. A constituição da Apib foi um marco histórico importante, pois ela criou novas organizaçôes regionais e locais. O segundo ciclo do movimento indígena consolidou o processo de centralização organizacional com a constituiçáo da Apib e de suas estruturas regionais, a Arpinpan e a Arpinsudeste, tentando replicar a experiência da Capoib e da Apoinme. Entretanto, tal modelo de expansão encontrou novamente dificuldades de se consolidar no Mato Grosso do Sul. É aqui que iremos centrar nossa análise: na tentativa de construção da Apib-Arpipan e na replicação do modelo de organização regional no Mato Grosso do Sul.

A hipótese que iremos desenvolver, a partir da análise da formação das organizaçóes indígenas do Mato Grosso do Sul, é de que a experiência do movimento indígena é profundamente condicionada pela luta entre dois sistemas políticos: ${ }^{10}$ um sistema de centralização organizacional com descentralização do poder; e um sistema de centralização organizacional com centralização do poder. Eles expressam diferentes posiçôes no sistema interétnico, bem como diferentes estratégias e visóes de mundo dos segmentos dos povos indígenas. O processo de centralização do poder, entretanto, tende a provocar a descentralização ou fissão organizacional. A história e a experiência do movimento indígena podem ser entendidas desse modo, já que os processos de centralização organizacional que tentaram estabelecer uma centralizaçáo do poder em nível nacional resultaram sempre em descentralização e fissão (as experiências da UNI/Unind e da Capoib sinalizam para isso).

Desse modo, a multiplicidade de organizações indígenas não é apenas um fenômeno quantitativo, mas qualitativo. Os diferentes tipos de organização indígena podem ser vistos como a expressáo de uma contradição entre um projeto de centralização organizacional com centralização do poder e um projeto de centralização organizacional com descentralização do poder. Iremos analisar, a partir da tentativa de construçáo da Apib no Mato Grosso do Sul, como se deu a luta entre estes dois tipos de centralização e de sistemas políticos. ${ }^{11}$ 


\section{Estrutura versus antiestrutura:}

\section{os conselhos-assembleias indígenas e as insurgências regionais}

Faremos, a seguir, a descrição etnográfica de duas assembleias indígenas (uma assembleia da Apib e uma Assembleia do Povo Terena) usando o método da análise situacional. Consideraremos as assembleias como situações sociais e adotaremos a técnica de análise de casos desdobrados ou dramas sociais (Gluckman, 1987; Oliveira Filho, 1988; Turner, 1974; Van Velsen, 1988). O mapa a seguir apresenta algumas informaçóes gerais sobre as terras indígenas Terena, necessárias ao entendimento da situação social aqui descrita.

\section{Mapa 1 - Terras indígenas Terena}

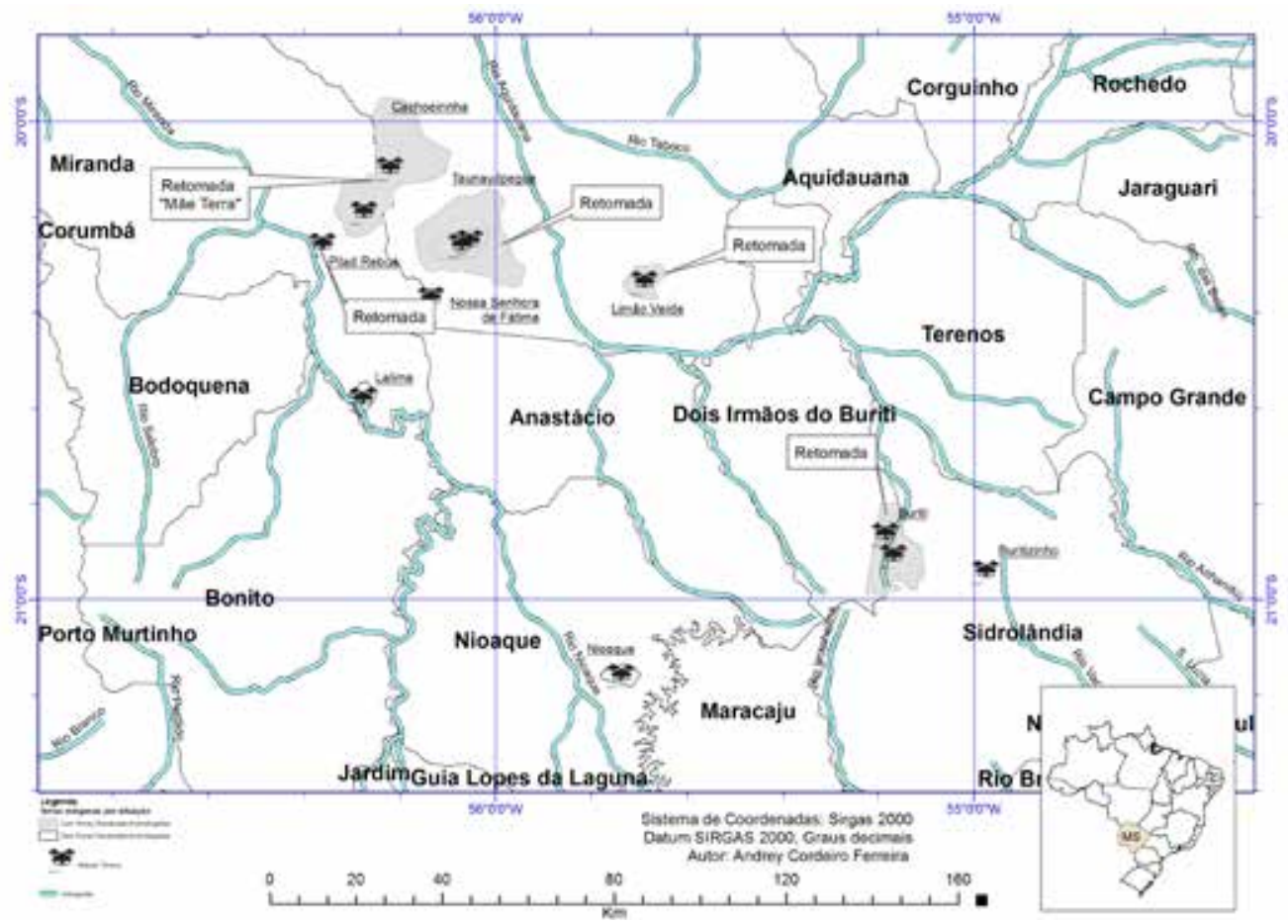

Fonte: Elaboração própria.

Em 2012, durante as atividades da pesquisa de campo, tivemos a oportunidade de participar de uma assembleia da Arpipan. Acompanhamos um grupo de lideranças da Retomada Mãe Terra (uma das mais importantes do Mato Grosso do Sul, localizada na cidade de Miranda), que participaria da assembleia na Aldeia Lalima, nas margens do Rio Miranda. Nessa assembleia, entraram em choque dois grupos: o grupo organizado em torno da Retomada Máe Terra e um grupo de antigos administradores e funcionários da Funai. Alguns líderes da 
Retomada Mãe Terra nos relataram conflitos envolvendo o grupo da retomada e o grupo de indígenas, que eles identificavam como antigos funcionários da Funai, referentes à participação deles no movimento indígena nacional. Eles afirmaram categoricamente que a Arpipan nasceu "dentro da Mãe terra, que a Mãe Terra é a maior expressão da Luta do Povo Terena”. Segundo essas lideranças, o grupo de funcionários de Funai, ligado a Marcos Terena, organizou uma assembleia da Arpipan - grupo que estaria próximo do governador André Pucinelli, um dos maiores articuladores das campanhas contrárias às demarcaçóes das terras indígenas no Mato Grosso do Sul. Existia também, segundo eles, uma disputa pela representação internacional (contaram que Marcos Terena dizia que "não existia organização indígena no Brasil" em eventos internacionais). Segundo esse grupo, organizado em torno da retomada, "a Arpipan foi tomada por peixes da cidade, que têm discurso, falam bonito, mas náo devem nos representar. Hoje quem tá na direção da Arpipan é o PPS (Partido Popular Socialista). Não passou pela base, pela comunidade..."

A assembleia que acompanhamos foi convocada para eleger a diretoria da Arpipan. Em meio a debates acirrados, o grupo de oposiçáo questionou a realização da assembleia da Arpipan e sua legitimidade, inclusive para escolher a diretoria. Um dos presentes lembrou a história da Capoib, "em que um diretor presidente centralizava o recurso". Um ponto interessante foi colocado por Lindomar Ferreira, ${ }^{12}$ um dos líderes da retomada, questionando um documento elaborado por um dos diretores da Arpipan e enviado à Funai, solicitando que esta "excluísse ele da representação na Apib na assembleia dos povos". Lísio Lili, um dos diretores da Arpipan, falou que "é bom que as lideranças reclamem... Nós nunca dissemos que representamos as lideranças. Para nós a liderança indígena é uma coisa e Arpipan é outra. A Arpipan foi constituída na época da construçấo do CNPI - ela não é uma organização indígena. $\mathrm{O}$ ministério pediu a criação da organização. Não é verdade que a Arpipan é uma entidade fechada”.

O dissenso se expressou numa profunda diferença quanto à própria concepção da organização: os então diretores da Arpipan apontavam que ela era uma organizaçáo criada para ser interlocutora do Estado na gestão de açóes e políticas públicas; os opositores entendiam que ela deveria ser uma articulação das lutas coletivas dos povos indígenas do Mato Grosso do Sul. O resultado é que o grupo de opositores se retirou da assembleia, por náo reconhecer a legitimidade dela, e para tentar inviabilizar a votação por falta de quórum. ${ }^{13}$

O conflito nessa assembleia da Arpipan foi apenas parte do início de outro processo organizativo. Os líderes e caciques indígenas ligados às retomadas de terras e açóes coletivas organizaram as Grandes Assembleias do Povo Terena 
(Hánaiti Ho’únevo Terenoe) a partir de 2012. Entre 2012 e 2014, foram realizadas cinco assembleias e constituídas novas organizaçôes indígenas, o Conselho do Povo Terena e o Conselho do Povo Kinikinau. Além disso, as assembleias indígenas passaram a reunir representantes das retomadas e caciques, sendo espaços em que se organizavam açóes políticas coletivas e também onde se dava a articulação com a Apib e o movimento indígena nacional. $\mathrm{O}$ documento de resolução da primeira assembleia do Povo Terena, por exemplo, indica como sua última resolução: "Fica decidido também, que a partir dessa data, apenas conselho da hánaiti ho' únevo têrenoe (grande assembleia do povo terena) e conselho da aty guasu (assembleia do povo guarani/kaiowá) podem falar em nome dos povos indígenas de Mato Grosso do Sul”. Desse modo, a criação do Conselho do Povo Terena, sem se restringir a ser uma contraposição à Arpipan, materializou uma luta de sistemas políticos, como ficará claro mais adiante. A criação do Conselho do Povo Terena marcava, assim, o esvaziamento da representatividade da Arpipan.

O conselho do povo Terena tomou por modelo o Conselho Aty Guasu Guarani, sendo, em certa medida, uma fissão da Arpipan, aglutinando todos aqueles que não reconheceram a legitimidade dela. Por outro lado, essas organizaçóes, especialmente o Conselho do Povo Terena, formulou uma etnopolítica determinada: unificar as aldeias e demandas do povo Terena; unificar as demandas e lutas dos Terena com os Guarani e demais povos indígenas do Mato Grosso do Sul; unificar as açóes com a Apib e o movimento indígena nacional. Dessa forma, a base objetiva dessa organização surgiu de experiências de retomadas (ação coletiva de retomada, decisão coletiva em reuniōes comunitárias, trabalho em roças coletivas) e deu um sentido de associar uma aliança interétnica à identidade genérica de "indígena".

Em 2014, acompanhamos uma das assembleias do Povo Terena, que, com o Conselho do Povo Terena, constituíram um novo sistema político de organização e ação indígena no Mato Grosso do Sul. A Grande Assembleia do Povo Terena (ou Hánaiti Ho’únevo Terenoê) expressa também muitas das ambiguidades que marcaram a assembleia da Arpipan e que configuram o choque de sistemas políticos.

A Grande Assembleia do Povo Terena chegou à sua quinta edição em maio de 2014. Realizada na Aldeia Babaçu, Terra Indígena Cachoeirinha, teve início em 8 de abril, com a apresentação cultural dos povos indígenas. Das 27 aldeias Terena existentes em 8 terras indígenas do Mato Grosso do Sul, 10 caciques estavam presentes ou representados, ou seja, 1/3 dos caciques. Vários líderes de retomadas também. No primeiro dia, a assembleia previa uma mesa com o tema "Territórios Tradicionais: desafios e perspectivas”, com a participação do Ministério Público Federal, do Departamento de Proteção Territorial da Funai, da Apib, do Cimi, 
da Secretaria de Articulação Social da Presidência da República (SDH) e da Justiça Global. ${ }^{14}$ Ao fim da mesa, ocorreria o debate com as lideranças indígenas. Nos demais dias estavam previstas outras mesas, sendo que, no segundo dia, foi realizado um ato político, o bloqueio da rodovia BR 262, como parte dos protestos contra a PEC 215 e uma audiência pública na Assembleia Legislativa do Mato Grosso do Sul (Alems) sobre o tema.

Iremos centrar a descrição e análise no primeiro dia, pois todos tinham a mesma estrutura. A primeira mesa foi marcada pelo clima de tensão e comoção, devido a acontecimentos que envolviam a luta pela terra, especialmente, a realização da audiência pública na Alems sobre a PEC 215. O informe da realização dessa audiência foi acompanhado pelas advertências de que havia "espiōes" na Assembleia Terena (que gostariam de levar informações e fazer com que os índios participassem da audiência com a finalidade de legitimá-la). Dessa forma, a Assembleia Terena estava sendo realizada numa relação de polarização com a "audiência pública de parlamentares e ruralistas", uma iniciativa do Estado do Mato Grosso do Sul.

Além disso, a violência contra os povos indígenas marcou e deu uma dimensão emocional à abertura do evento. Cartazes em homenagem a Marçal de Souza (Guarani) e Oziel Gabriel (Terena, morto em 2013) estavam atrás da mesa onde eram realizadas as apresentaçóes dos componentes. Uma faixa da grande Assembleia Terena e do Conselho do Povo Terena compunham o espaço principal da assembleia, realizada em um barracão construído para receber reunióes comunitárias. $\mathrm{Na}$ abertura foi feito um pequeno rito, com a leitura de uma lista com dezenas de nomes de indígenas assassinados no Mato Grosso do Sul; a cada nome lido, o plenário respondia "presente", um sinal de respeito e reconhecimento da importância histórica dessas pessoas.

A mesa inicial contou com a participação de representantes de Estado que atuam diretamente nos processos de demarcação territorial e/ou na defesa e articulação de direitos sociais indígenas. Depois da mesa com as autoridades, foi dada a palavra aos líderes indígenas. A fala de Lindomar, pela Apib, foi no sentido de marcar a constituição de um movimento indígena:

numa larga caminhada, não deixamos companheiros caídos ou deixados para trás. Essa nossa caminhada começou na Terra Taunay. As pessoas diziam "mais uma organização perdendo tempo, fazendo politicagem”. A Assembleia do Povo Terena não é para fazer politicagem, mas para lutar pelos direitos indígenas e retomar as terras que estão com fazendeiros produzindo para sustentar os europeus com soja, milho... 
Uma liderança indígena também se posicionou, afirmando que o elemento principal do dia era decidir se os indígenas participariam da audiência pública e que "um deputado estaria enviando um ônibus para levar índios com a finalidade de legitimar a Audiência”. Essa preocupação com a participação na audiência pública estava relacionada ao problema da "representação" e ao direito legítimo de falar em nome dos povos indígenas. A audiência pública pretendia deslegitimar o Conselho do Povo Terena. Outra liderança falou que náo adiantava escolher pessoas ou procurar indivíduos, pois "nossas decisôes são tomadas coletivamente". E assim foi informado que a Apib não estava participando destas audiências nacionalmente. Os representantes do MPF e da Funai falaram que estas instituiçóes não enviariam representantes, respeitando a decisão do movimento indígena. Esta tensão expressava o posicionamento de lideranças indígenas contrárias à PEC 215 e também sua estratégia de "pressionar" os representantes de Estado. Dessa forma, as intervençóes e falas foram perpassadas pelo tema da demarcação de terras e da violência e também pela contraposição à audiência pública organizada pelos ruralistas. À tarde, a plenária deliberou pela aprovação de uma nota de repúdio e também pela realizaçáo de um ato no dia seguinte, em protesto contra a audiência pública. A nota foi lida e aprovada por aclamação.

Ao final da fala das lideranças e dos integrantes da mesa, ocorreu um ato político comandado por uma liderança da Retomada da Aldeia Moreira e por moradores de três aldeias (Moreira, Passarinho e Lalima, todas de Miranda). O grupo se concentrou em frente à mesa, e o líder, em tom imperativo, depois de bater na mesa (o que fez com que os representantes da Funai se levantassem, assustados), começou a cobrar uma posição de esclarecimento sobre a estagnação do processo de demarcação. Este ato de cobrança da Funai foi seguido pela cobrança dos moradores da Retomada Boa Esperança sobre a Portaria Declaratória da Terra Indígena Taunay. Em seguida, uma liderança de Dois Irmãos de Buritis relatou que a Administração Regional da Funai tinha auxiliado na sua prisão e de outras lideranças, levando-os para Polícia Federal. ${ }^{15}$ Vários outros questionamentos se seguiram, por exemplo, a indicação do administrador regional de Campo Grande, que desrespeitou um acordo feito com os caciques e propôs um nome chancelado pela presidência da Funai. O cacique de Nioaque perguntou: "até quando vamos aceitar enlatado vindo de Campo Grande e Brasília? É preciso fazer retomada, se unir e colocar patrício na Funai". O ato político encerrou as atividades da parte da manhã. A tônica foi a denúncia e a cobrança da Funai sobre as razões por que ela não encaminha ações de demarcação de terras, descumpre acordos políticos e não permite que os índios influenciem nas decisóes do órgão. O fato de lideranças e moradores de terras 
indígenas em processo de demarcação ou retomada serem os protagonistas dessa cobrança e crítica está relacionada a dimensôes da organização social indígena, como veremos adiante.

A assembleia indígena mostra uma estrutura interna de funcionamento que diz bastante sobre a dinâmica e as ambiguidades da etnopolítica. A assembleia foi dividida em alguns momentos: primeiro, as falas das "autoridades", em que os representantes do Estado (como MPF e Funai) são dotados do poder da palavra; segundo, a abertura da palavra às chamadas "lideranças indígenas", expressando-se aí o antagonismo e a contestação da autoridade, pois os indígenas usam da liberdade de fala para refutar as narrativas oficiais ou cobrar a eficácia de suas ações; terceiro, as ações políticas, que são também ações simbólicas, como a pressão sobre os representantes da Funai e o bloqueio das rodovias; quarto, o encerramento, em que acontecem brincadeiras e desafios, inclusive para definir o local das assembleias seguintes, ou em que a palavra é aberta aos indígenas em geral, que não as lideranças. ${ }^{16}$

A forma de funcionamento da assembleia-conselho indígena traz muitos aspectos do universo simbólico e ritual Terena. De maneira geral, a assembleia reproduz a estrutura de um dos principais rituais de integração entre os Terena, o Dia do Índio: o momento da fala das autoridades e o encerramento com jogos de rivalidade estão presentes também naquele ritual. ${ }^{17}$ Porém, a assembleia introduz dois componentes, a fala indígena de denúncia-cobrança e a ação de resistência ou de força contra os representantes da autoridade do Estado. Essa ambiguidade faz parte da dialética dos sistemas políticos. A ação de exigênciadenúncia expressa também a especificidade da etnopolítica indígena: um líder, respaldado por um grupo de indígenas (moradores, homens e mulheres), cerca os representantes do Estado e os coloca perante uma iminente (e imprevisível) ação (que poderia ser o sequestro ou uma agressão), deixando-os assim numa posição de vulnerabilidade, invertendo as posiçôes simbólicas e de poder, mesmo que temporariamente. Ao mesmo tempo, questiona a função da Funai (do Estado) e ressalta o poder de "cobrança" que os índios deveriam exercer (várias vezes isso foi colocado: que "a cobrança" deve ser feita). A ação produz um significado; é um rito, porque mostra como o poder do líder indígena está amparado na comunidade ou grupo indígena que o segue, e que não existe, naquele momento, uma separação entre líder e comunidade. Esta ação política, que pode também ser considerada como rito (porque pode ser lida por sua dimensão simbólicoexpressiva), foi reproduzida diversas vezes. Há um padrão de cobrança dos representantes do Estado, tema que perpassou por toda a assembleia indígena. 
O sistema político da assembleia-conselho indígena é, assim, centrado sobre três fundamentos: a força coletiva dos grupos indígenas; a conquista da liberdade de palavra diante da autoridade do Estado e a inversão ritual do poder; e o uso da força ou da violência coletiva náo letal como forma de resistência, como representado pelas açóes de bloqueio de rodovia e pelas cobranças, por meio da intimidaçáo aos representantes de Estado. Por outro lado, a estrutura da assembleia reproduz certa hierarquia, não contemplando a fala da comunidade a não ser no final. Desse modo, a etnopolítica da assembleia Terena toma, em grande medida, como modelo um ritual identitário.

Em resumo, podemos afirmar o seguinte. As duas assembleias explicitaram um conflito organizacional. Idealmente, a Arpipan deveria funcionar como a organização representativa regional da Apib. Mas seu modelo, de associação civil, permitiu que um determinado grupo ou conjunto de açóes tomasse o controle da entidade, centralizando o poder decisório. Na visão desse grupo, a Arpipan existia para ser interlocutora do Estado, e não representante dos povos e lideranças indígenas. A criação das assembleias-conselhos indígenas expressou outros segmentos ou grupos da sociedade Terena e, de fato, esvaziou a representatividade da Arpipan na Apib, de modo que, na prática, são os conselhos-assembleias indígenas os reais articuladores da Apib e do movimento indígena no Mato Grosso do Sul. A assembleia-conselho indígena institui uma descentralização do poder, pois distribui o poder decisório entre uma multiplicidade de caciques e lideranças de retomadas. Nesse espaço, essas lideranças mantêm entre si uma relação horizontal, de igualdade de poder sobre as ações da organização indígena. Ou seja, a mesma dualidade entre centralização organizacional e centralização de poder versus centralização organizacional com descentralização do poder se manifestou no Mato Grosso do Sul, ocorrendo um esvaziamento temporário da Arpipan, de suas funções de organização indígena. Ao mesmo tempo, a própria assembleia-conselho indígena tem ambiguidades, pois o Estado se faz presente como um ator central dentro da dimensão ritual ou simbólica da organização, como um interlocutor necessário, mesmo que haja um confronto. Além disso, a própria assembleia-conselho tenta funcionar como um espaço de poder de indicação de representantes de Estado (como de gestores da Funai). A micropolítica da organização indígena se sobrepõe à micropolítica do indigenismo.

A experiência de construção da Apib no Mato Grosso do Sul resultou numa luta de organizaçóes, a Arpipan versus os conselhos-assembleias indígenas. Essa foi a luta entre a estrutura ou sistema político centralizador hierárquico e um sistema político descentralizado horizontal. Essas organizaçóes expressam 
diferentes sistemas políticos, que são produtos da história colonial, das formas de resistência indígena e dos próprios sistemas interétnicos regionais.

\section{Indigenismo e micropolítica:}

\section{a formação de um sistema centralizado segmentar faccional}

Para compreender essa situação social, e a polarização entre as organizaçóes indígenas, devemos levar em consideração a história do indigenismo e sua micropolítica. A formação do Estado nacional no século XX no Brasil criou um regime de gestão dos povos indígenas, o regime tutelar. Independentemente da forma de governo (ditadura ou democracia), esse regime de tutela permaneceu inalterado por quase um século, como parte de um modelo hierárquicoassimilacionista que caracterizava a relação dos novos Estados da América Latina com os povos indígenas (Ferreira, 2008; Lima, 1995; Oliveira Filho, 1988). $\mathrm{O}$ regime tutelar se materializou na construção do indigenismo, como ideologia e política de gestáo territorial dos povos indígenas. $\mathrm{O}$ indigenismo levou à construção de um sistema político centralizado nas aldeias e reservas indígenas, que nós denominados de sistema segmentar-faccional (Ferreira, 2013b; Nicholas, 1966). O processo de centralização do poder visava à criação de um único cacique para uma terra indígena. Nesse sistema político, o poder era exercido por meio de um "cacicado" (grupo de líderes e chefes, reconhecidos pelo Estado e umbilicalmente ligados aos seus interesses, que frequentemente eram recrutados entre lideranças tradicionais).

A criação dessa estrutura política tutelar, somada às estruturas diversas de representação e governo, gerou diversos papéis inter-hierárquicos (Gluckman, 1968), ou seja, posiçóes que eram parte não somente da estrutura do complexo mercado-Estado, mas também da própria dinâmica e organizaçáo social indígena (Ferreira, 2013b, 2014a, 2015). Estes papéis introduziram ou reforçaram formas de poder coercitivo e centralizado dentro das sociedades indígenas, de forma que diversas facçóes indígenas se constituíram monopolizando e usando o poder de Estado para subordinar facóes e segmentos rivais. Esse sistema político foi aprofundado, quando, seguindo os modelos de tutela internacional da ONU, recomendou-se o recrutamento de indígenas para servir como funcionários de Estado. No Brasil, esse dispositivo foi instituído pelo Estatuto do Índio em 1973 e levou à formação de uma camada de administradores ou burocracia indígena com formação profissional que foi incorporada à gestão no Estado, por meio do órgão indigenista. Logo, várias sociedades indígenas mantiveram relaçôes simbólicas, políticas e orgânicas com o Estado nacional, como os Terena, no Mato Grosso do Sul. ${ }^{18}$ 
Esses papéis inter-hierárquicos negam completamente o dualismo "tradicional/ moderno e branco/indígena" e "interno/externo". O sistema centralizador hierárquico reúne organizações de Estado, mas também organizações e lideranças tradicionais indígenas, que participam dos processos decisórios dentro da aldeia para a escolha de caciques e até de indicaçóes de indígenas para cargos de governo. Essa relação pode ser percebida pelo exemplo citado: um diretor da Arpipan enviou documento à Funai solicitando que esta destituísse Lindomar da representação na Apib. Isso mostra como lideranças indígenas consideram a Funai e o poder coercitivo do Estado como parte legítima da organizaçáo social indígena, acionando-a para resolver conflitos. ${ }^{19}$ Esse processo é recorrente entre os indígenas e mesmo entre grupos subalternos. É ingênuo conceber então a centralização hierárquica como um fenômeno meramente imposto e exterior, pois ela obedece a lógicas internas ao grupo étnico. Esse poder se estende e se exerce em rede nas aldeias através de uma multiplicidade de papéis inter-hierárquicos. O indigenismo, então, criou uma estrutura organizacional (o SPI, depois a Funai, depois vários outros espaços de poder) que praticamente fundiu a organizaçáo social Terena com a micropolítica destas instituiçôes.

$\mathrm{O}$ indigenismo e esse sistema político assumiram duas estruturas territoriais ao longo da história: a das reservas (pequenas unidades territoriais dedicadas à assimilação dos indígenas), que coincidiu basicamente com o SPI; e a das terras indígenas, unidades territoriais direcionadas à preservação dos indígenas, que correspondeu à lógica de atuação da Funai na Amazônia legal. As terras demarcadas pelo SPI tinham em média 5 mil hectares, enquanto que as da Funai tinham 181 mil hectares (Ferreira, 2013). Isso significa que o indigenismo criou uma divisão entre povos indígenas com terra e sem terra, de modo que o Mato Grosso do Sul colocou os povos indígenas na condição de sem terra na geopolítica do indigenismo. O sistema político centralizado segmentar faccional ajudava, assim, a manter essa distribuição territorial, pois funcionava como um sistema que direcionava as açóes dos grupos indígenas para a competição por recursos escassos e pela obediência à autoridade.

Por outro lado, desenvolveu-se o que podemos chamar de infrapolítica, uma atividade de resistência de líderes e segmentos indígenas. A busca por autonomia dos grupos domésticos perante o cacicado e o Estado levou a uma multiplicação de lideranças informais ou não autorizadas, que assumiram a forma de faccionalismo religioso, com a multiplicação de igrejas e, depois dos anos 1990, do associativismo. Por isso denominamos o sistema político de segmentar-faccional, pois a centralização estatal gerava, paradoxalmente, uma descentralização organizacional em múltiplas facções. Essa descentralização 
segmentar-faccional não representava autonomia ou contestação ao poder de Estado; ao contrário, dirigia as facções para a reprodução do sistema político, pela busca do monopólio e centralização do poder e exercício da dominação sobre as demais facçôes indígenas, ou pela simples fuga deste. Desse modo, o Estado, por meio do indigenismo, construiu um sistema político segmentar-faccional que era o fundamento local do regime tutelar. A micropolítica do indigenismo supunha, assim, que a própria etnopolítica fosse absorvida por ele. Essa situação só se transformaria com a eclosão do conflito territorial.

\section{$O$ conflito territorial e a insurgência indígena:}

\section{a infrapolítica e o sistema descentralizado horizontal}

As mudanças macropolíticas enfraqueceram ainda mais a tentativa de imposição de um sistema político centralizado e criaram as condiçóes para a emergência de um novo sistema político. A crise do regime militar e do modelo de Estado hierárquico assimilacionista, bem como a entrada em cena das políticas neoliberais e da globalização, provocou uma profunda transformação no indigenismo e no regime tutelar. A emergência de um movimento indígena nacional e a generalização de formas de insubordinação e resistência, durante os anos 1980, convergiram para que o modelo hierárquico assimilacionista de ordenamento jurídico fosse substituído por um modelo isonômico pluralista, consolidado na Constituiçáo Federal de 1988 e num novo ordenamento jurídico internacional, mesmo com todas as contradiçôes (Ferreira, 2008; Figueiredo, 2011). Aliada a tais transformaçôes, no nível local da política, emergiu o que chamamos de insurgência, quando os povos indígenas do Mato Grosso do Sul se valeram de diferentes formas de resistência para lutar por terra, levando à intensificação da conflitualidade territorial. ${ }^{20}$ Entre 1998 e 2004, foram registradas pelo Movimento Nacional dos Produtores, organizaçáo ruralista, 49 ocupaçóes de terras por indígenas no Mato Grosso do Sul, especialmente pelos Guarani (Ferreira, 2013b), sem contar os bloqueios de rodovia, os sequestros e as ocupaçóes de prédios públicos.

O conflito territorial foi central para a emergência de um novo sistema político. Esse conflito acompanhou os ciclos do movimento indígena nacional. Nos anos 1980 e 1990, a principal forma de ação era a reivindicação da demarcação de terras indígenas de acordo com as normas constitucionais. As demarcaçóes de terras realizadas pelo Estado entre os Terena tiveram início em meados dos anos 1990. Três casos foram emblemáticos: Limão Verde (1997), Dois Irmãos de Buritis (1998) e Cachoeirinha (1999). Essas demarcaçóes foram todas obstaculizadas por açóes judiciais e morosidade administrativa. De fato, mesmo com processos de 
demarcação de terra concluídos, os Terena não tiveram posse e uso efetivo da terra na maioria dos casos. Esses conflitos desencadeariam uma série de ações coletivas, como bloqueio de rodovias e ocupação de fazendas direcionadas para a conquista da posse efetiva da terra. Entre 2003 e 2005, o Cimi incentivou a realização de diversas assembleias indígenas entre os Terena, para organizar a reivindicação da conclusão dos processos de demarcação. Vários caciques Terena tomaram parte nas assembleias e passaram a participar dos eventos nacionais do movimento indígena, como o Acampamento Terra Livre.

O conflito territorial foi um desdobramento do conflito interno nas aldeias, próprio da micropolítica do indigenismo. No âmbito das aldeias, foram desenvolvidas formas de resistência de indígenas diante do poder dos caciques e das facçóes. Normalmente os caciques participavam de coalizóes políticas locais que envolviam proprietários de terras e importantes lideranças políticas regionais, que tinham o interesse em que as demarcaçóes de terras não avançassem. Para que a luta pela terra acontecesse, foi necessária uma luta interna nas aldeias, normalmente contra o poder do cacique geral. ${ }^{21}$ Essa infrapolítica dentro das aldeias, contra a imposição de um sistema político centralizado por meio do indigenismo, foi uma condição para o surgimento de um novo sistema político. Isso ficou explícito no caso de Cachoeirinha, terra indígena onde foi realizada a retomada Mãe Terra e de onde surgiram algumas das principais lideranças da Apib. Entre 2004 e 2005, formou-se um bloco que reuniu lideranças da aldeia Argola, que romperam com seu cacique. Este grupo dissidente uniuse a dois caciques, das aldeias Babaçu e Lagoinha, e decidiu pela realização de açôes de retomada de terras, contra a vontade do cacique geral da aldeia. Em 2006 foi realizada a primeira retomada de terras em Cachoeirinha, a da Fazenda Santa Vitória.

A heterogeneidade do grupo que realizou a retomada é extremamente importante de observar: dois caciques, um presidente de associação e lideranças reconhecidas apenas pela sua atividade de luta geraram um novo tipo de etnopolítica. A ação coletiva de retomada foi um primeiro passo; depois foram instituídas na retomada roças coletivas e uma coordenação composta por 12 membros escolhidos em assembleia dos participantes da retomada. Eles várias vezes rechaçaram a autoridade do cacique geral e sua tentativa de se colocar como representante e líder legítimo. A partir dessa estrutura organizativa, foram feitas diversas ações coletivas (retomadas, bloqueios etc.) Entre 2007 e 2012, este grupo, em articulação com diversos grupos similares constituídos em outras aldeias Terena (especialmente de Dois Irmãos de Buriti e outras retomadas), aprofundou sua participação na Apib. 
Esse novo modo de etnopolítica encontrou nas retomadas, nas estratégias de resistência por meio do conflito territorial, um solo fértil de desenvolvimento. Porém, foram as contradições do próprio sistema político segmentar-faccional que forneceram as bases necessárias para tal. Os caciques e as lideranças dissidentes, normalmente aqueles excluídos das relaçóes privilegiadas com o Estado, ficavam na posição de campesinato sem terra e proletariado rural ou urbano pobre, e sem meios de operar como provedores eficientes, em razão dos monopólios exercidos pelos caciques gerais. Estes caciques e outras lideranças constituem a base das retomadas e por isso sua presença nas assembleias-conselhos indígenas é tâo destacada.

Por isso, a cisão entre organizaçóes indígenas é expressão de um processo mais complexo. Os sistemas políticos, no sentido aqui empregado, resultam de uma prática e atividade histórica. Para a construção desses sistemas, cabe distinguir a combinação de dois tipos de centralização e descentralização: centralização do poder decisório e centralização organizacional (entendendo-se por isso a criação de uma organização maior que engloba organizaçôes menores); e descentralização do poder decisório e descentralização organizacional (isolamento de organizaçóes que não pertencem a organizaçóes maiores). O quadro a seguir aponta esses tipos de modelo de sistemas políticos e suas contrapartidas históricas.

\section{Quadro 2 - Sistemas políticos no movimento indígena e sistemas interétnicos}

\begin{tabular}{|c|c|c|}
\hline & $\begin{array}{c}\text { Descentralização } \\
\text { organizacional }\end{array}$ & Centralização organizacional \\
\hline $\begin{array}{c}\text { Centralização do } \\
\text { poder decisório }\end{array}$ & $\begin{array}{c}\text { Sistema centralizado } \\
\text { segmentar faccional }\end{array}$ & $\begin{array}{c}\text { Organizações indígenas no Estado } \\
\text { (UNI, Capoib, Arpipan) }\end{array}$ \\
\hline $\begin{array}{c}\text { Descentralização do } \\
\text { poder decisório }\end{array}$ & $\begin{array}{c}\text { Sistemas segmentares } \\
\text { mutualistas e } \\
\text { "movimento indígena" }\end{array}$ & $\begin{array}{c}\text { Organizações indígenas contra o Estado } \\
\text { (Apib, conselhos indígenas) }\end{array}$ \\
\hline
\end{tabular}

Fonte: Elaboração do autor.

O sistema centralizado segmentar faccional praticamente funde a etnopolítica com a micropolítica das instituiçóes estatais, tornando-a um inferior local da política estatal. A centralização organizacional com centralização do poder tem um efeito parecido, e fracassou diversas vezes. É o sistema político que combinou descentralização do poder com centralização organizacional que tem conseguido materializar a unidade interétnica e, igualmente, expressar a reivindicação territorial. Desse modo, é impossível compreender essa etnopolítica do movimento 
e organizaçóes indígenas sem compreender esse sistema político descentralizado insurgente, que deriva do conflito territorial, do sistema interétnico regional, e do qual uma das expressôes são os conselhos-assembleias indígenas.

\section{A dialética da política:}

\section{entrando e saindo do Estado}

A etnopolítica é um fenômeno fundamental da política contemporânea, especialmente na América Latina. $\mathrm{O}$ que podemos chamar de movimentos e organizaçôes indígenas tem influenciado grandes reformas constitucionais (como a da Bolívia e a do Equador, nos anos 2000), movimentos revolucionários armados (como o zapatismo, no México) e experiências de organização internacionalista (como a Ação Global dos Povos, APG). Também tem sido um ator e interlocutor estratégico da gestáo territorial e do conflito territorial, como demonstram os casos de interlocução com o Banco Mundial e o indigenismo em escala continental, bem como os conflitos de terras envolvendo povos indígenas. Hoje, mais do que nunca, é impossível pensar o Estado nacional sem pensar a etnopolítica como fator de sua transformação e/ou funcionamento. Inversamente, a etnopolítica não é uma forma exterior à modernidade e ao Estado nacional, ao contrário, está politicamente e ontologicamente permeada por ele (como pudemos observar pela importância simbólica e organizacional do Estado para determinados segmentos indígenas). Desse modo, o estudo do movimento e das organizaçôes indígenas é um aspecto fundamental da política no sentido englobante, amplo e plural, da grande política. Toda teoria que não leve em consideração a etnopolítica é uma forma parcial, e na maioria das vezes reducionista, de política, e vice-versa.

O movimento e as organizaçóes indígenas no Brasil, por sua vez, não podem ser pensados apenas como um movimento social, ou seja, como uma rede de organizaçóes de representação e ação política. Como tentamos demonstrar, a tentativa de construção da Apib no Mato Grosso do Sul acabou produzindo distintas organizaçóes (Arpipan versus assembleia-Conselho), que expressam conflitos de sistemas políticos. Os sistemas interétnicos regionais condicionam a própria configuração do movimento indígena nacional, sendo o caso do Mato Grosso do Sul emblemático desse processo. A primeira experiência de formação de uma organização indígena nacional, a UNI, teve um papel destacado de lideranças do Mato Grosso do Sul, e as características da etnopolítica da região se refletiram nos impasses nacionais. O Mato Grosso do Sul representa um caso fundamental para a compreensão do funcionamento das organizações indígenas, pois mostra como a dialética centralização/descentralização pode se manifestar de formas históricas muito variadas. As primeiras tentativas de criar uma organização 
indígena nacional fracassaram. Em certa medida, isso expressou a recusa do movimento indígena em adotar um modelo de centralização organizacional com centralização do poder. A criação da Apib tentou instituir um sistema de centralização organizacional com descentralização do poder. Mas a Apib, ao exportar o modelo de organizaçóes regionais para um estado como o Mato Grosso do Sul, acabou gerando os mesmos impasses. As especificidades históricas e do sistema interétnico regional fizeram com que a estrutura da Apib caísse num processo de centralização do poder e fosse abandonada pelos indígenas. No caso dos Terena, eles criaram outro sistema político, descentralizado insurgente, de mobilização e representação, para contrapor a este, tomando por base a experiência da Aty Guassu Guarani.

A antropologia e a etnologia podem, desse modo, dar uma importante contribuição ao estudo da política. Entretanto, a antropologia (nas suas escolas e paradigmas dominantes) estabeleceu como norma que a alteridade dos sistemas políticos tradicionais ou primitivos estava radicada na sua exterioridade em relação ao mundo moderno, colonial e imperial. Ou seja, os sistemas segmentares, os Estados tradicionais e as sociedades sem Estado eram fenômenos pré-modernos, e estes só poderiam manter sua identidade enquanto sistema sendo exteriores ao Estado e à modernidade (como no caso das teses funcionalistas, no estilo de Radcliffe-Brown), ou numa permanente atividade "contra o Estado", em razão de uma filosofia indígena (como no caso de Clastres).

Essas abordagens, por mais relevantes que tenham sido suas contribuiçóes (e efetivamente o foram), perderam uma dimensão fundamental: o caráter dialético da relação dos sistemas políticos (suas ambiguidades, relaçóes de complementaridade e antagonismo). Foram autores como Turner, Gluckman, Barth, Wolf e Nicholas, entre outros, e mais recentemente Scott, que chamaram a atenção para a necessidade de pensar o Estado moderno e o sistema mundial colonial como um fator organizacional e simbólico dos grupos étnicos. Nesse sentido, as estratégias de centralização organizacional com centralização do poder não são apenas imposiçóes externas, mas dependem de complexos arranjos organizativos e da criação de papéis interculturais e inter-hierárquicos. Do mesmo modo, a "sociedade contra o Estado" não é um a priori mental e cultural; as formas antiestatais emergem de uma infrapolítica, historicamente determinada. Existem indígenas atuando no e contra o Estado, e oscilando entre estas posiçóes, a partir das mesmas referências culturais e rituais. A existência de um sistema político centralizado hierárquico e estatal, parte da própria estrutura do Estado nacional, e outro sistema político descentralizado insurgente pode parecer paradoxal, mas não é. Eles mantêm relações de complementaridade, ambiguidade 
e antagonismo. É possível “entrar e sair" dos dois sistemas ou atuar em ambos simultaneamente (Leach, 1995). ${ }^{22}$ No nosso entendimento, os sistemas políticos são criações históricas, e as condiçôes de sua duração e reprodução são complexas. A possibilidade de entrar e sair dos dois sistemas políticos introduz uma grande margem de instabilidade e imprevisibilidade política no Estado e nas próprias organizaçóes e no movimento indígena.

A etnopolítica, no nosso entendimento, não é o resultado do desaparecimento do sistema tradicional em favor de formas "modernas" de movimentos sociais, nem o ressurgimento de tipo "tribalista" do sistema tradicional (como sugerem as teses instrumentalista e primordialista da etnicidade), mas uma permanente criação prática, surgindo em resposta à situação histórica colonial e às assimetrias econômicas, sociais e de poder. Ao mesmo tempo, como vimos, a etnopolítica expressa modos culturais e rituais que lhe conferem sua singularidade. Os sistemas políticos são, desse modo, situacionais. $\mathrm{O}$ conflito entre sistemas políticos não pertence ao passado pré-moderno, ao contrário, surge de situaçóes históricas, marcadas por relaçóes assimétricas e de conflitualidade, como modos de ação e organização da atividade política. Por isso a antropologia e a abordagem dialética podem dar grandes contribuiçóes ao estudo do Estado e da etnopolítica.

Recebido em 10/8/2015

Aprovado em 10/10/2016

Andrey Cordeiro Ferreira é doutor em antropologia social pela UFRJ e professor da UFRRJ. Autor do livro Tutela e resistência indigena (2013), tem pesquisas nas áreas de política e etnicidade, território, cultura e relaçôes de podersaber. Contato: andreycf2099@gmail.com 


\section{Notas}

1. Apesar de ser um conceito empregado de forma relativamente recorrente, não existem muitas definiçóes claras do conceito de etnopolítica. De todo modo, estamos agrupando aqui as teses e análises sobre os chamados "povos primitivos" ou "sociedades tradicionais", que na realidade foram justamente as bases da elaboração sobre política na antropologia. Desse modo, os estudos sobre sistemas políticos africanos (Pritchard, 1981), os sistemas políticos da alta Birmânia (Leach, 1995), os Estados tradicionais (Geertz, 1991) e as formas de sociedade contra o Estado (Clastres, 2003b), bem como como a situação colonial (Balandier, 1993; Gluckman, 1987), têm em comum essa característica: tomam como objeto formas de política marcada por uma profunda alteridade em relaçáo à política entendida como atividade de Estado. O que estamos denominando de etnopolítica engloba todos esses temas, já que são, no limite, a política de grupos e sistemas interétnicos.

2. Cabe destacar a importância de estudos de Roberto Cardoso de Oliveira e Joáo Pacheco de Oliveira, no Brasil, para a construção da análise situacional da política. A própria noção de fricção interétnica, considerada exatamente uma dialética entre "índios e brancos" no Brasil, é fundamental para pensar as relaçôes interétnicas.

3. A dialética do político foi pensada por Evans-Pritchard em termos de fussão/ fusão, por Leach como dialética entre sistemas políticos hierárquicos e igualitários e por Turner como dialética entre estrutura e antiestrutura. Todas as elaboraçôes são formas de colocar a dialética entre centralização e descentralização.

4. A teoria sociológica dialética aqui empregada foi particularmente desenvolvida por Pierre-Joseph Proudhon e Mikhail Bakunin, no século XIX, e no século XX por Georges Gurvitch, no qual a dialética aparece ao mesmo tempo como método e como movimento real e concreto (Gurvitch, 1982, 1987; Schwartzman, 1960).

5. As teorias da etnicidade têm, hoje, uma longa história. De todo modo, é preciso lembrar que o conceito de etnicidade entrou no léxico científico pós-II Guerra Mundial, basicamente para recobrir uma multiplicidade de grupos que antes eram enquadrados em categorias como "raça" ou "povo". Desse modo, a noção de etnia e etnicidade remete a um complexo discursivo que tenta delimitar fronteiras sociais a partir de critérios de origem biológica, histórica e cultural (Glazer, Moynihan \& Schelling, 1975; Poutignat \& Streiff-Fenart, 1997). As teorias da etnicidade da antropologia social aqui evocadas combateram os determinismos biológico e cultural, formulando um conceito relativo e situacional de grupo étnico.

6. É importante lembrar que a categoria índio é uma categoria da situação colonial e, durante muito tempo, foi recebida pelos grupos étnicos como discriminatória e imposta. A ideia de um movimento indígena supóe, assim, a assimilação e ressignificação de uma categoria simbólica de classificação de origem colonial. Esta categoria gera uma dupla identidade étnica, a identidade genérica de índio (que opera para demarcar o pertencimento a esse universo genérico de povos que foram objeto da colonização), 
nos limites de um Estado nacional (e por isso a ideia de índio se mescla com a de nacionalidade), e as múltiplas identidades particulares, como Guarani, Terena, Paresi, Xavante etc. Logo, quando falamos da indianidade, falamos de uma identidade criada pelo Estado e por imposição da situação colonial. Quando falamos de etnicidade, falamos de formas de autoclassificação originariamente exteriores ao Estado, mas interconectadas com a indianidade nos quadros das relações coloniais e dos sistemas interétnicos.

7. Ocorreu um conflito entre Marcos Terena e Domingos, seu tio, em 1982, quando os dois se consideravam presidente da UNI/Unind. Esse conflito, que envolveu financiamento internacional e organismos de apoio, teria terminado com o desligamento de Marcos Terena da organização.

8. "Para Ramos, sua restrita representatividade e a distorção de seu gerenciamento, vindo de cima parabaixo, nunca chegaram a ser resolvidos. Além disso, ela nunca conseguiu refletir a realidade de pequenas sociedades dispersas e politicamente desvinculadas entre si. Dificuldades semelhantes, e por razóes similares, enfrentou o Capoib [...] com a perspectiva de representar os vários povos indígenas do país" (Bicalho, 2010:270).

9. O nosso artigo "Desigualdade e diversidade no Brasil dos 500 anos: etnografia da conferência e marcha indígena" analisa uma série de fatores da divisão do movimento indígena. Podemos destacar dois aqui: primeiro, existia um setor do movimento indígena cujo projeto principal era a construção de mecanismos de cogestáo do Estado e das políticas públicas e do financiamento internacional. Esse grupo não queria uma política de confronto com o governo. E havia outro setor, que estava interessado na mobilização e ação direta de luta por terra. Apesar de conceber também a necessidade de participação dos indígenas nos espaços de poder, esse segundo grupo assumia uma política de resistência e ruptura em relação ao Estado e às elites regionais. O segundo fator é que se manifestou um conflito em torno da definiçấo da "indianidade", em que o governo de FHC, na época, investiu na imagem do índio puro e autêntico como único interlocutor legítimo do Estado. Isso repercutiu no discurso de várias lideranças e em conflitos cotidianos dentro da conferência, em que indígenas do Nordeste, como os Tuxá, eram questionados acerca de sua autenticidade por índios como os Xavante, por exemplo, dando margem a interessantes diálogos e conflitos interculturais acerca da indianidade (Ferreira; Lima, 2008).

10. Empregamos aqui o conceito de sistema político de um modo distinto da controvérsia clássica. De maneia geral, o conceito de sistema (político, de parentesco etc.) foi empregado para demarcar algumas propriedades: interdependência; regularidade ou capacidade de autorreprodução; território; fechamento em si mesmo. Do modo que estamos empregando aqui, o conceito de sistema é o mesmo sugerido por Barth e outros autores, em que os sistemas são abertos, ou seja, as fronteiras entre um sistema e outro são porosas e ambíguas. Além disso, existia certa controvérsia se os sistemas eram unidades ideais/abstratas ou concretas. Aqui consideramos que os sistemas são objetivos e subjetivos ao mesmo tempo. O sistema político é, assim, um modo de organização 
da atividade política composto de unidades interdependentes, autorreproduzido e aberto; ele tem propriedades formais, aqui denominadas de dialética entre centralização e descentralização, que, combinadas, geram sistemas políticos concretos, como demonstraremos adiante.

11. Estamos aqui empregando a distinção entre projetos políticos de "autonomias no Estado" e "autonomias contra o Estado". A centralização organizacional é uma outra forma de falar de um projeto de autonomia no Estado. É uma forma desenvolvida por certos setores do movimento indígena que acredita na necessidade de construir uma representação indígena no interior do Estado nacional. Os outros creem num projeto de "resistência indígena".

12. Lindomar Ferreira é hoje uma das mais importantes figuras da Apib e do Conselho do Povo Terena.

13. Seguindo o modelo de organização civil sem fins lucrativos, a Arpipan tinha associados individuais com direito de voto. Essa estrutura colocava a autoridade nas mãos de indivíduos associados e não reconhecia representantes indígenas. Dessa forma, o conflito entre representação coletiva e individual também perpassou pela assembleia, sendo que a estrutura associativa coloca esse dilema.

14. Mesa 2: Saúde Indígena em Mato Grosso do Sul; Funase e DSEI; Secretaria Estadual de Saúde; Secretaria Municipal de Saúde. Mesa 4: Sustentabilidade e Meio Ambiente; Diretoria de Desenvolvimento Sustentável (Funai); MDS; Ministério da Pesca; Conselho Gatti. Debates com as lideranças. Mesa 3: Retomada da Educaçáo Escolar Indígena; Representante Indígena no Conselho de Educaçâo Escolar Indígena no MEC; Representante dos Povos do Pantanal no MEC; Representante Guarani Kaiowá no MEC; Secretaria Municipal de Educação; Secretaria Estadual de Educação. Debates com as lideranças indígenas.

15. O representante da presidência da Funai replicou informando que existe "Funai e Funai" - que, da mesma maneira que ocorreu o fato relatado, existiram outras situaçóes em que a Funai auxiliou as ações do movimento indígena e a proteção de sua vida.

16. $\mathrm{O}$ ato de encerramento consistiu de dois momentos. O primeiro foi protagonizado pelo grupo de bate-pau da Retomada Máe Terra, que fez uma apresentação do rito e marcador diacrítico que simboliza a identidade Terena. Depois se passou a algumas falas e rezas, com apresentação do que seria, talvez, o último koixomuneti de Cachoeirinha, que apresentou uma de suas rezas e cânticos, no que foi acompanhado por Nailton Pataxó. A parte final foi dedicada à votaçáo do Conselho do Povo Terena, para a escolha do local da nova assembleia. O processo decisório também foi marcado por características específicas: a votação sobre a audiência na Alems foi tácita, por exemplo, e a participação mais difusa leva a uma configuração particular - não foi um espaço de disputa pelo voto. A eleição da nova sede consistiu numa disputa entre dois caciques que deveriam apresentar as razóes e vantagens de realizar a assembleia nas suas respectivas aldeias (e os moradores também gritavam argumentos, como abundância de peixe, no caso de 
Lalima, belezas naturais etc.) O cacique da aldeia Babaçu fez a mediação. Depois de cada cacique apresentar sua aldeia candidata, foi pedido que os presentes se manifestassem, e aquele que fizesse mais barulho (com palmas, assovios e gritos) seria o vencedor. Essa brincadeira também é realizada no Dia do Índio, ao final da dança do bate-pau. Lalima foi eleita (o cacique de Babaçu que coordenava a reunião sugeriu diplomaticamente que havia sido empate, mas os presentes se manifestaram novamente e ele declarou a vitória de Lalima). Foi feito um minuto de silêncio em memória de Oziel Terena, bem como uma reza por Nailton Pataxó, e a assembleia foi encerrada.

17. O Dia do Índio é um ritual que expressa o que chamamos de cosmo-história, ou seja, uma cosmologia indígena transformada pela história é um modo de interpretação dessa mesma história. No caso, os Terena assimilaram o conceito de Nação na sua cosmologia (Ferreira, 2011b, 2013).

18. No caso dos Terena, ocorreu uma transformação histórica da cultura e identidade indígena, como a formação de uma cosmologia que incorporou a categoria "nação" como símbolo e desenvolveu um conceito de autoridade e uma ética de respeito pela autoridade, estendida do âmbito doméstico (da autoridade dos mais velhos e da chefe do grupo doméstico) até as autoridades de Estado. Esse sistema existiu, no Mato Grosso do Sul, de forma praticamente inalterada por 80 anos, entre 1905 e 1990.

19. Esse fenômeno é frequente e estrutural entre os Terena: recorrer ao Estado para eliminar líderes e opositores de posiçóes de poder (Ferreira, 2013; Oliveira, 1976).

20. Estamos denominando de insurgência um tipo de processo político em que grupos subalternos usam formas de violência coletiva não letal para atingir objetivos políticos (Ferreira, 2016). Os povos indígenas do Mato Grosso do Sul, no final dos anos 1990, adotaram táticas de resistência e formas de violência coletiva não letal, como bloqueios de rodovia, ocupação de prédios públicos ou retomadas de terras.

21. A Terra Indígena Cachoeirinha, como ademais diferentes reservas e povos, tem uma estrutura complexa. São cinco aldeias (Cachoeirinha ou Sede, Argola, Babaçu, Morrinho e Lagoinha), cada uma com um cacique. A relação entre as aldeias é tensa, pois a multiplicação das aldeias não foi um processo autorizado e harmônico, mas perpassado por conflitos. Assim, o Estado, através da Funai, criou a figura do cacique geral, que teria autoridade sobre os demais caciques. Essa estrutura centralizada engendrou conflitos cíclicos entre o cacique geral, os caciques e outras lideranças (como presidentes de associaçóes), que passaram a lutar pelo poder de representar os indígenas e gerir recursos.

22. Cremos que essa foi uma das principais proposiçóes de Leach em Sistemas políticos da Alta Birmânia: a alternância entre formas políticas gumla e gumsao. 


\section{Referências}

ADAMS, Richard Newbold \& BASTOS, Santiago. 2003. Las relaciones étnicas en Guatemala, 1944-2000. Centro de Investigaciones Regionales de Mesoamérica Guatemala.

BALANDIER, Georges. 1969. Antropologia politica. Barcelona: Península. 1993. "A noção de situação colonial". Cadernos de Campo, v. 3.

BARTH, Fredrik. 1965. Political leadership among Swat Pathans. London: Athlone Press. 1976. Los grupos étnicos y sus fronteras. México: Fondo de Cultura Econômica. . 2000. O guru e o iniciador e outras variaçôes antropológicas. Rio de Janeiro: Contra Capa Livraria.

BICALHO, Poliene S. d. S. 2010. Protagonismo indígena no Brasil: movimento, cidadania e direitos 1970-2009. Tese de doutorado, UnB.

BONFIL BATALLA, Guillermo. 1978. "Las nuevas organizaciones indígenas (hipótesis para la formulación de un modelo analítico)". Journal de la Société des Américanistes: 209-219.

CASTORIADIS, C. 1985. A experiência do movimento operário. São Paulo: Brasiliense.

CLASTRES, P. 2003. A sociedade contra o Estado: pesquisas de antropologia política. São Paulo: Cosac \& Naify.

EVANS-PRITCHARD, E. E. 1978. Os Nuer: uma descrição do modo de subsistência e das instituiçóes politicas de um povo nilota. São Paulo: Perspectiva.

FERREIRA, A. C. 2002. Mudança cultural e afirmação identitária: a antropologia, os Terena e o debate sobre aculturação. Dissertação de Mestrado, UFRJ.

. 2008. Desigualdade e diversidade no Brasil dos 500 anos: etnografia da conferência e marcha indígena. Antropologia e direitos humanos $V$. Brasília; Rio de Janeiro: ABA, Bookl.

2011. "Etnicidade, territorialização e agronegócio: as frentes de expansão agrícola e as dinâmicas econômicas Terena e Paresi”. $35^{\circ}$ Encontro Anual da Anpocs. Minas Gerais, ANPOCS.

. 2013a. "Economia e organização do território: reciprocidade, redistribuição e troca nas fronteiras do capitalismo flexível”. In: Henri Acselrad (org.). Cartografia social, terra e território. Rio de Janeiro: Armazém das Letras. pp. 177-200. 
. 2013b. Tutela e resistência indígena: etnografia e história das relaçôes de poder entre os Terena e o Estado brasileiro. Sáo Paulo: EDUSP.

. 2014a. Acumulação flexivel e dialéticas do trabalho: reestruturação produtiva e povos indígenas na cadeia mercantil da agroindústria. Rio de Janeiro: UFRJ.

.2014b. Teoria do poder, da reciprocidade e a abordagem coletivista: Proudhon e os fundamentos da ciência social no anarquismo. Rio de Janeiro: UFRRJ.

. 2015. Trabalho, etnicidade e economia-mundo: o papel da ambientalização da política econômica na expropriação moral da condição de trabalhador indígena. Rio de Janeiro: UFRRJ.

FIGUEIREDO, André V. 2011. O caminho quilombola: sociologia jurídica do reconhecimento étnico. Curitiba: Appris.

FOUCAULT, Michel. 1979. Microfisica do poder. Rio de Janeiro: Graal.

GLUCKMAN, Max. 1968. "Inter-hierarchical roles: professional and party ethics in tribal areas in South and Central Africa”. In: Marc J. Swartz. Local-level politics: social and cultural perspectives. Chicago: Aldine.

1987. "Análise de uma situação social na Zululândia moderna”. In: B. FeldmanBianco \& G. L. Ribeiro. Antropologia das sociedades contemporâneas. Sáo Paulo: Global. pp. 227-344.

GURVITCH, G. 1982. As classes sociais. São Paulo: Global.

1987. Dialética e sociologia. São Paulo: Vértice.

LEACH, E., R. 1995. Sistemas politicos da Alta Birmânia. São Paulo: EDUSP.

LIMA, A. C. d. S. 1995. Um grande cerco de paz: poder tutelar, indianidade e formação do Estado no Brasil. Petrópolis: Vozes.

NICHOLAS, Ralph W. 1966. "Segmentary factional political systems". In: Marc J. Swartz, Victor W. Turner \& Arthur Tuden. Political anthropology. Chicago: Aldine. pp. 49-59.

OLIVEIRA, Kelly. 2013. Diga ao povo que avance! Movimento indígena no Nordeste. [s.l: s.n.].

OLIVEIRA FILHO, João Pacheco de. 1988. O nosso governo: os Ticuna e o regime tutelar. São Paulo: Marco Zero; MCT-CNPq. . 1999. A viagem da volta: etnicidade, politica e reelaboração cultural no Nordeste indigena. [s.l.]: Contra Capa Livraria. v. 2. 
2006. Hacia una antropología del indigenismo: estudios críticos sobre los processo de dominación y las perspectivas politicas actuales los indigenas en Brasil. Rio de Janeiro: Contra Capa.

SCOTT, James. Los dominados y el arte de la resistencia: discursos ocultos. México: ERA, 2000.

SIDER, Gerald. 1993. Lumbee Indian histories: race, ethnicity and Indian identity in the Southern United States. Cambridge: Cambridge University Press.

POULANTZAS, Nicos. 1977. Poder político e classes sociais. Sáo Paulo: Martins Fontes. PROUDHON, Pierre-Joseph. 1986. Críticas às constituiçôes: Proudhon os grandes cientistas sociais. São Paulo: Ática. . 2001. Do princípio federativo. São Paulo: Imaginário.

RADCLIFFE-BROWN, A. 1981. "Prefácio e introdução". In: Meyer Fortes \& E. E. Evans-Pritchard. Sistemas politicos africanos. Lisboa: Calouste Gulbenkian.

SWARTZ, M. J. 1968. Local level politics - social and cultural perspectives. Chicago: Aldine.

SWARTZ, Marc J.; TURNER, Victor W. \& TUDEN, Arthur. 1966. Political anthropology. Chicago: Aldine.

TURNER, Victor. 1974. O processo ritual. Petrópolis: Vozes.

EdUFF. .2008. Dramas, campos e metáforas: ação simbólica na sociedade humana. Niterói,

WEFFORT, F. C. 2001. Os clássicos da política. São Paulo: Ática. 


\section{Resumo}

O objetivo deste trabalho é, a partir da apresentação de algumas reflexóes sobre o movimento indígena no Brasil, especialmente de uma de suas principais organizações, a Articulação dos Povos Indígenas do Brasil (Apib), desenvolver elementos para uma teoria do que podemos chamar de etnopolítica. Propomos que, no processo histórico de formaçáo do movimento indígena, existe uma luta entre duas tendências contraditórias (uma dialética que rege a etnopolítica), que se manifesta na experiência das organizaçóes indígenas: a de centralizaçáo organizacional com centralização do podereadecentralização organizacional com descentralização de poder. No caso concreto, iremos estudar como a tentativa de estruturação da Apib no Mato Grosso do Sul se desdobrou num conflito que deu origem a duas organizaçóes, o Conselho do Povo Terena (organização informal) e a Articulação dos Povos Indígenas do Pantanal (Arpipan), organização formal que deveria ser a seção regional da Apib. Essas duas organizaçôes expressam, justamente, essa luta entre formas de centralização e descentralização do poder, bem como as ambiguidades do processo de organização indígena. Esse conflito, interno ao movimento indígena, é na realidade a expressão do conflito entre o que podemos chamar de sistema político centralizador hierárquico estatal (ou estrutura) e um sistema político descentralizador insurgente igualitário (ou antiestrutura).

Palavras-chave: etnopolítica, movimento e organizaçooes indígenas, etnicidade, movimentos sociais, sistemas políticos.

\section{Abstract}

The aim of this work is to develop elements for a theory of ethnopolitics based on the presentation of some reflections on the indigenous movement in Brazil, especially one of its main organizations, the Articulation of the Indigenous Peoples of Brazil (Apib). In the historical process of formation of the indigenous movement, we propose there is a struggle between two contradictory tendencies (a dialectic that governs ethnopolitics), which is manifested in the experience of indigenous organizations: that of centralization of organization with centralization of power, and that of organizational centralization with decentralization of power. In this case, we study how the attempt to structure Apib in Mato Grosso do Sul unfolded in a conflict that gave rise to two organizations, the Terena People's Council (an informal organization) and the Articulation of the Pantanal Indigenous Peoples (Arpipan), a formal organization that should be a regional section of Apib. These two organizations rightly express this struggle between forms of centralization and decentralization of power, as well as the ambiguities of the process of indigenous organization. This conflict, internal to the indigenous movement, is in fact the expression of the conflict between what we might call a centralizing hierarchical state political system (or structure) and a decentralized insurgent egalitarian (or anti-structure) political system.

Key-words: Ethnopolitics, indigenous movement and organizations, ethnicity, political systems, social movements. 